Article

\title{
Surveillance Studies Reveal Diverse and Potentially Pathogenic-Incriminated Vector Mosquito Species across Major Botswana Touristic Hotspots
}

\author{
Mmabaledi Buxton 1,*, Casper Nyamukondiwa ${ }^{1}{ }^{(}$, , Ryan J. Wasserman ${ }^{1,2}$, Victor Othenin-Girard ${ }^{3}$,

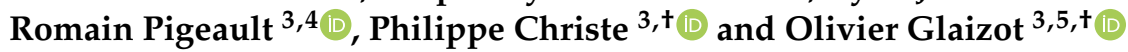 \\ 1 Department of Biological Sciences and Biotechnology, Botswana International University of Science and \\ Technology, P/Bag 016, Palapye 10071, Botswana; nyamukondiwac@biust.ac.bw (C.N.); \\ ryanwas21@gmail.com (R.J.W.) \\ 2 Department of Zoology and Entomology, Rhodes University, Makhanda 6140, South Africa \\ 3 Department of Ecology and Evolution, University of Lausanne, 1015 Lausanne, Switzerland; \\ victor.othenin-girard@unil.ch (V.O.-G.); romain.pigeault@univ-poitiers.fr (R.P.); \\ philippe.christe@unil.ch (P.C.); olivier.glaizot@unil.ch (O.G.) \\ 4 EBI Ecologie \& Biologie des Interactions (UMR 7267), Université de Poitiers, 86000 Poitiers, France \\ 5 Museum of Zoology, 1014 Lausanne, Switzerland \\ * Correspondence: lodybuxton@hotmail.co.uk \\ + Joint last authors.
}

Citation: Buxton, M.;

Nyamukondiwa, C.; Wasserman, R.J.; Othenin-Girard, V.; Pigeault, R.; Christe, P.; Glaizot, O. Surveillance Studies Reveal Diverse and

Potentially Pathogenic-Incriminated Vector Mosquito Species across Major Botswana Touristic Hotspots. Insects 2021, 12, 913. https://doi.org/ $10.3390 /$ insects 12100913

Academic Editor: Geoffrey M. Attardo

Received: 27 August 2021 Accepted: 20 September 2021 Published: 6 October 2021

Publisher's Note: MDPI stays neutral with regard to jurisdictional claims in published maps and institutional affiliations.

Copyright: (C) 2021 by the authors. Licensee MDPI, Basel, Switzerland. This article is an open access article distributed under the terms and conditions of the Creative Commons Attribution (CC BY) license (https:// creativecommons.org/licenses/by/ $4.0 /)$.
Simple Summary: Mosquitoes vector pathogens that cause burdening diseases in humans, livestock and wildlife worldwide. Spatially and temporally, mosquito diversity varies considerably in response to bio-physical environments. As such, there is a need for mosquito diversity and distribution studies, as well as monitoring programmes, to inform on the risk of associated diseases. This survey assessed mosquito species in three major touristic areas of Botswana that are likely to harbour pathogens across prevailing hosts. The results revealed that all regions surveyed had important mosquito groups (Anopheles, Aedes and Culex) that are threats to public, wildlife and livestock health globally, including the arid Central Kalahari Game Reserve. The findings represent useful species inventories for future surveys and monitoring programmes.

Abstract: Vector mosquitoes contribute significantly to the global burden of diseases in humans, livestock and wildlife. As such, the spatial distribution and abundance of mosquito species and their surveillance cannot be ignored. Here, we surveyed mosquito species across major tourism hotspots in semi-arid Botswana, including, for the first time, the Central Kalahari Game Reserve. Our results reported several mosquito species across seven genera, belonging to Aedes, Anopheles, Culex, Mansonia, Mimomyia, Coquillettidia and Uranotaenia. These results document a significant species inventory that may inform early warning vector-borne disease control systems and likely help manage the risk of emerging and re-emerging mosquito-borne infections.

Keywords: Central Kalahari Game Reserve; Chobe enclave; emerging-re-emerging diseases; mosquitoborne infections; Okavango; vector mosquitoes

\section{Introduction}

Arthropods are economically important organisms given their role in the global transmission of disease to humans, livestock and wildlife [1,2]. Amongst arthropods, mosquitoes are by far the most important vector species contributing to global human and animal health burdens [3,4]. Indeed, Aedes, Anopheles, Culex and Mansonia have been implicated as the main vector mosquito groups of medical and veterinary importance [5]. Vector mosquitoes transmit pathogens (e.g., viruses, protozoans and helminths) that cause diseases such as Zika, dengue, West Nile fever, yellow fever, Rift Valley fever, types of 
encephalitis (such as Japanese and St. Louis), chikungunya, filariasis and human and avian malaria [6-9]. Owing to the socio-economic burdens brought about by vector mosquitoes, adequate and updated knowledge on their species diversity, spatio-temporal distribution and abundance are thus key in monitoring and evaluating prevalence and the risk of their associated diseases.

The proliferation of mosquito vectors and associated pathogens poses a challenge in health and epidemiological systems, mainly in Africa [10]. Given the increase in invasive vector species with climate change [11], increased human populations, trade and globalisation [12,13], invasive vector mosquito species could exacerbate this problem. Indeed, mosquitoes contribute immensely to the global socio-economic burden of a global crisis in rising invasive insect species, and their economic costs are increasing significantly $[14,15]$. Mosquito species have the potential to successfully establish in diverse landscapes influenced by foraging (e.g., host availability, nectar dietary resources [16] or climatic niches [17]). Thus, in areas where there is a broad feeding preference (e.g., humans, livestock and wildlife), and favourable abiotic factors, mosquito species are likely to proliferate [18]. As such, novel environmental monuments such as game reserves and national parks with potentially diverse animal hosts, human influx, vegetation and perennial water supplies become a crucial ecological platform for vector-pathogen and host interaction fostering emerging and re-emerging mosquito-borne disease transmission dynamics [19]. Therefore, there is need for robust and continuous monitoring across major mosquito-vector-species risk pathways to update the inventory status [18].

In Africa, the most prominent mosquito-borne disease is malaria [20] (but also see Willcox et al. [21]; Mwanyika et al. [22]), accounting for $\sim 400,000$ deaths annually [23]. As such, most of the published works have mainly focused on Anopheles vector species and their pathogen incrimination surveillance [24] (but see Braack et al. [9]). Similarly, in Botswana much work is focused on human malaria vectors, neglecting other species [25]. In addition, mosquito research is also spatially skewed, mostly based in the malaria endemic zone (northern part) of the country and around permanent human habitation [26]. As such, there is a need for more holistic vector and pathogen surveillance that collectively covers all potential vector/parasite species and across different spatial scales.

Here, we assessed the diversity of mosquito vector species in major tourism hotspot regions of Botswana, including the Okavango Delta, the Chobe enclave and, for the first time, the Central Kalahari Game Reserve (CKGR). Currently, tourism is the second largest foreign exchange earner in Botswana, after diamonds [27]. Ecotourism comprises about $5 \%$ of the gross domestic product of the country's economy [28], with the Okavango Delta, the Chobe enclave and the CKGR being the main centres of tourist activities [29]. Whilst previous works on mosquito diversity and vector competence have been conducted in parts of the Okavango and Chobe areas and other parts of the country [26,30,31] (see Table 1), there is still much exploration required given the potential anthropogenic and climate change likely to impact vector distribution and abundance [32]. This study thus provides an important species diversity database that may help strengthen vector surveillance, disease risk analysis and early warning systems in high-risk regions that are frequented by travelling humans. 
Table 1. Identified mosquito species in Botswana belonging to genera Anopheles, Aedes, Culex and Mansonia.

\begin{tabular}{cccc}
\hline Anopheles & Aedes & Culex & Mansonia \\
\hline An. arabiensis & Ae. mcintoshi & Cx. pipiens & Ma. uniformis \\
An. parensis & Ae. aegypti & Cx. poicillipes & \\
An. longipalpis type C & & Cx. neavei & \\
An. leesoni & & & \\
An. quadriannulatus & & & \\
An. funestus s.s & & \\
An. rivulorum & & \\
An. pharoensis & & & \\
An. nili & & & \\
An. rufipes & & & \\
An. distinctus & & \\
An. squamosus & & \\
An. ziemanni & & \\
An. demeilloni & & \\
An. marshalli & & & \\
An. vaneedeni & & \\
An. rhodesiensis & & & \\
An. seretsei & & & \\
Refs [26,31,33-35] & & & \\
\hline
\end{tabular}

\section{Materials and Methods}

\subsection{Study Site and Mosquito Collection}

Sampling was done in March 2019 under Ministry of Environment, Natural Resources Conservation \& Tourism of the Republic of Botswana research permit number ENT 8/36/4 XXXX II (10/82). Adult mosquitoes were sampled around 5 artificial water holes in the north-east of the Central Kalahari Game Reserve (CKGR, Ghanzi District, 1 night per station, Figure 1) as well as in the Chobe enclave, at the VanThuyne-Ridge (VTR) Research Centre (Chobe District, 5 nights, Figure 1).

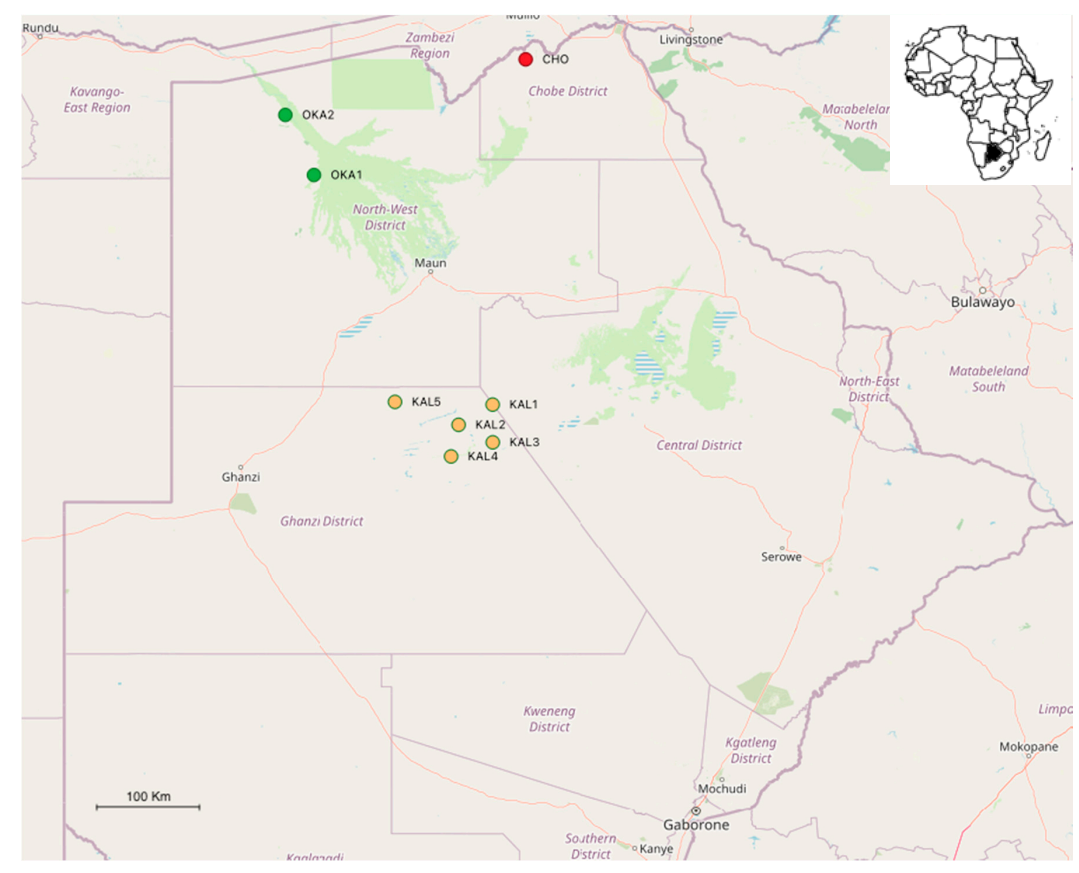

Figure 1. Map of Botswana with sampling stations: North-East Central Kalahari Game Reserve (CKGR)—KAL1 to KAL5; Okavango Delta-OKA1 and OKA2; and the Chobe enclave-CHO. See Table 2 for details of stations. Thumbnail picture shows the location of Botswana in Africa. 
In February 2020, 2 stations west of Okavango (North-West District) were prospected during 3 and 2 nights, respectively. Sampling was done again at the VTR Research Centre for 5 nights (Figure 1; Table 2). All samples were collected during the summer season of the southern hemisphere, when vector mosquitoes are most abundant [38].

Table 2. Locations and mosquito sampling dates across areas of touristic destinations in Botswana between March 2019 and February 2020.

\begin{tabular}{|c|c|c|c|c|}
\hline Location & Site & Sampling Dates & Station Code & GPS Coordinates \\
\hline \multirow[t]{2}{*}{ Chobe enclave } & \multirow[t]{2}{*}{$\begin{array}{l}\text { VanThuyne-Ridge } \\
\text { Research Centre }\end{array}$} & 18-22nd March 2019 & $\mathrm{CHO}$ & \multirow[t]{2}{*}{$\begin{array}{l}18^{\circ} 06^{\prime} 44.5^{\prime \prime} \mathrm{S} \\
24^{\circ} 18^{\prime} 58.4^{\prime \prime} \mathrm{E}\end{array}$} \\
\hline & & 8-12th February 2020 & $\mathrm{CHO}$ & \\
\hline \multirow{7}{*}{$\begin{array}{c}\text { Central Kalahari Game } \\
\text { Reserve }\end{array}$} & Etsha & 3-5th February 2020 & OKA1 & $\begin{array}{l}19^{\circ} 08^{\prime} 18.1^{\prime \prime} \mathrm{S} \\
22^{\circ} 20^{\prime} 04.1^{\prime \prime} \mathrm{E}\end{array}$ \\
\hline & Nxamasere & 6-7th February 2020 & OKA2 & $\begin{array}{l}18^{\circ} 36^{\prime} 22.6^{\prime \prime} \mathrm{S} \\
22^{\circ} 03^{\prime} 59.1^{\prime \prime} \mathrm{E}\end{array}$ \\
\hline & Matswere Gate & 12th March 2019 & CKGR1 & $\begin{array}{l}21^{\circ} 09^{\prime} 23.4^{\prime \prime} \mathrm{S} \\
24^{\circ} 00^{\prime} 25.7^{\prime \prime} \mathrm{E}\end{array}$ \\
\hline & Sunday Pan & 13th March 2019 & CKGR2 & $\begin{array}{l}21^{\circ} 19^{\prime} 58.3^{\prime \prime} \mathrm{S} \\
23^{\circ} 41^{\prime} 18.4^{\prime \prime} \mathrm{E}\end{array}$ \\
\hline & Kalahari Plains Lodge & 14th March 2019 & CKGR3 & $\begin{array}{l}21^{\circ} 29^{\prime} 07.9^{\prime \prime} \mathrm{S} \\
24^{\circ} 00^{\prime} 30.1^{\prime \prime} \mathrm{E}\end{array}$ \\
\hline & Letiahau & 15th March 2019 & CKGR4 & $\begin{array}{l}21^{\circ} 36^{\prime} 30.3^{\prime \prime} \mathrm{S} \\
23^{\circ} 37^{\prime} 05.4^{\prime \prime} \mathrm{E}\end{array}$ \\
\hline & Motopi & 16th March 2019 & CKGR5 & $\begin{array}{l}21^{\circ} 07^{\prime} 57.9^{\prime \prime} \mathrm{S} \\
23^{\circ} 05^{\prime} 34.8^{\prime \prime} \mathrm{E}\end{array}$ \\
\hline
\end{tabular}

The CKGR is a hot desert region with a distinct dry (April to October) and wet (November to March) season. Semi-permanent but scarce artificial water bodies are found across the region. During the wet season, the landscape becomes green and dry with no rains [39]. The Okavango Delta is largely characterised by permanent streams and swampy basins to seasonal floodplains. Although the wet and dry seasons follow the same pattern as the CKGR, the Okavango Delta is rich in fauna and flora; however, both regions remain unique in attracting tourists from diverse local and international destinations [40]. Whilst the Chobe enclave consists of permanent river systems in the northern part of the district, which sustain wildlife, the southern region is relatively dry [41]. Sampling was carried out on the dry area (southern part) away from the Chobe River, i.e., around the VTR Centre (9 $\mathrm{km}$ south of Parakarungu village). Whilst the Chobe enclave and the Okavango Delta are largely characterised by a livestock and wildlife interface, the CKGR site is predominantly characterised by wildlife [42].

Six BG-Sentinel carbon-dioxide-baited traps (Biogents AG, Regensberg, Germany) were set in the afternoon $(1600 \mathrm{~h})$ and the mosquitoes were collected in the morning $(0600 \mathrm{~h})$. The specimens were preserved individually in $2 \mathrm{~mL}$ Eppendorf tubes with $80 \%$ ethanol. However, because of overwhelming adult mosquito catches in the Okavango (up to $1500 /$ night), the mosquitoes were first separated into their genera in the field using gross morphology [43] and then stored by identified taxon in 25 or $50 \mathrm{~mL}$ vials.

\subsection{Sample Identification and Analyses}

All specimens were identified morphologically following the protocols of Jupp [43] under a stereo binocular microscope (Leica M205, Leica microsystems, Wetzlar, Germany). Further, 1 to 40 samples per taxon, depending on the number of individuals collected, were subjected to molecular identification following Buxton et al. [36]. Here, the cytochrome oxidase subunit I (COI) gene was amplified using LCO1490 (5'GGTCAACAAATCATAAAGATATTGG-3') and HCO2198 (5'-TAAACTTCAGGGTGACC AAAAAATCA-3') primers [44]. Sequences were examined with the BLAST algorithm in GenBank (accessed in June 2021). Molecular identification was used whenever blast 
identity was above $98 \%$. When sequences were not available in GenBank (or blast identity was $\leq 98 \%$ ), we used morphological identities. Unidentified specimens (morphological and molecular) were given to the genera level by groups of morphologically identical specimens (e.g., sp. 1, sp. 2).

Mosquito species richness (i.e., total species represented) per site was determined and abundances were analysed as proportions using percentages across sampled areas to compare dominance. The Shannon-Wiener diversity index was determined (equation 1), which takes into account the species abundance and evenness (i.e., the proportion of individuals amongst the different species sampled) following protocols of Khoobdel et al. [45]. Thus, the Shannon diversity index $\left(\mathrm{H}^{\prime}\right)$ was calculated as the summation of the product of species abundance probability $(\mathrm{Pi})$ and its natural logarithm $(\ln P i)$.

$$
H^{\prime}=-\sum P i \cdot \ln (p i)
$$

\section{Results}

A total of 5486 mosquitoes from 32 taxa of seven genera (Aedes, Anopheles, Culex, Mansonia, Mimomyia, Coquillettidia and Uranotaenia) were collected (Table 3). In the Chobe enclave (CHO), 173 mosquitoes of 9 species in 3 genera were recorded (Aedes: Ae. aegypti; Anopheles: An. gambiae s.s, An. squamosus gp. 1; and Culex: Cx. naevei/simpsoni, $C x$. perexiguus, $C x$. pipiens, $C x$. simpliciforceps, $C x$. wigglesworthi and $C x$. univittatus). Two unidentified Aedes specimens (Ae. sp. $1^{1}$ and Ae. sp. $\left.3^{1}\right)$ and eight unidentified Culex $(C x$. sp. $1^{1}$ ) were collected in Chobe as well (Table 3). Culex pipiens was the most dominant species $(75.72 \%)$, followed by An. gambiae s.s (11.56\%). Other mosquito taxa reported were few, ranging from one $(0.58 \%)$ to eight $(4.62 \%)$ specimens per taxa (Figure $2 a)$.

Table 3. Mosquito identification information of species collected from major tourism destinations (Central Kalahari Game Reserve (CKGR), Okavango (OKA) and Chobe enclave (CHO)) in Botswana. Specimens were identified morphologically (morph.), molecularly (mol.) or both (morph/mol.) as described in the Materials and Methods section. The GenBank reference is given with pairwise identities (\%). The GenBank corresponding reference, if available, is given whenever morphological identity is undefined at the species level.

\begin{tabular}{|c|c|c|c|c|c|c|}
\hline \multirow{2}{*}{ Genus } & \multirow{2}{*}{ Species } & \multicolumn{3}{|c|}{ Nb. Specimens } & \multirow{2}{*}{$\begin{array}{l}\text { Identification } \\
\text { (morph/mol.) }\end{array}$} & \multirow{2}{*}{ GenBank ID (\% Identity) } \\
\hline & & CKGR & OKA & $\mathrm{CHO}$ & & \\
\hline \multirow[t]{5}{*}{ Aedes } & Ae. aegypti & 1 & 0 & 2 & morph/mol. & MK533633 (99.2-99.8) \\
\hline & Ae. mcintoshi & 0 & 3 & 0 & mol. & LC473695 (97.9-99.8) \\
\hline & Ae.sp. $1^{1}$ & 3 & 0 & 1 & morph. & - \\
\hline & Ae. sp. $2^{1}$ & 4 & 0 & 0 & morph. & - \\
\hline & Ae. sp. $3^{1}$ & 0 & 0 & 1 & morph. & - \\
\hline \multirow[t]{8}{*}{ Anopheles } & An. coustani & 0 & 10 & 0 & mol. & MK585951 (98.3-99.7) \\
\hline & An. gambiae s.s & 0 & 74 & 20 & morph/mol. & NC_002084 (99.7-100) \\
\hline & An. squamosus gp. 1 & 0 & 0 & 1 & mol. & $\bar{M} K 776750$ (99.7) \\
\hline & An. squamosus gp. 2 & 0 & 34 & 0 & mol. & MK533644 (99.1) \\
\hline & An. sp. 1 & 6 & 0 & 0 & morph. & An. sp. 1 MT741511 (100) \\
\hline & An. sp. $2^{1}$ & 0 & 1 & 0 & morph. & 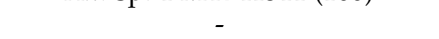 \\
\hline & An. sp. 3 & 0 & 1 & 0 & morph. & An. sp. Mali 1 MK585979 (99.4) \\
\hline & An. sp. 4 & 0 & 1 & 0 & morph. & An. sp. 15 MK776739 (98.7) \\
\hline \multirow[t]{3}{*}{ Coquillettidia } & Cq. fuscopennata & 0 & 111 & 0 & morph/mol. & LC473712 (98.3-99.1) \\
\hline & Cq. metallica & 0 & 4 & 0 & morph/mol. & LC473709 (99.8) \\
\hline & Cq. microannulata & 0 & 2 & 0 & morph/mol. & LC473713 (99.2-99.4) \\
\hline \multirow[t]{10}{*}{ Culex } & Cx. neavei/simpsoni & 0 & 229 & 1 & morph/mol. & $\begin{array}{c}\text { Cx. neavei LC473635 (97.4-98.6) } \\
\text { Cx. simpsoni KU187061 (96.9-98.0) }\end{array}$ \\
\hline & Cx. mirificus & 0 & 1 & 0 & mol. & LC473643 (100) \\
\hline & Cx. perexiguus & 3 & 0 & 3 & mol. & KU380423 (99.7-100) \\
\hline & Cx. pipiens & 26 & 10 & 131 & morph/mol. & MZ206334 (99.7-100) \\
\hline & Cx. poicilipes & 0 & 164 & 0 & morph/mol. & LC473618 (98.2-99.7) \\
\hline & Cx. rima & 0 & 111 & 0 & morph/mol. & KU380462 (99.2-99.7) \\
\hline & Cx. simpliciforceps ${ }^{2}$ & 0 & 0 & 3 & morph. & Cx. sp. LC507872 (98.8-99.1) \\
\hline & Cx. wigglesworthi ${ }^{2}$ & 0 & 0 & 1 & morph. & Cx. rima LC473615 (97.3) \\
\hline & Cx. sp. $1^{1}$ & 3 & 0 & 8 & mol. & $\begin{array}{c}\text { Cx. sp. 16GH LC507872 (98.9-99.8) } \\
\text { Cx. cinereus LC473617 (97.0) }\end{array}$ \\
\hline & Cx. univittatus ${ }^{3}$ & 1 & 8 & 1 & morph/mol. & LC102144 (99.0-99.7) \\
\hline
\end{tabular}


Table 3. Cont.

\begin{tabular}{|c|c|c|c|c|c|c|}
\hline \multirow{2}{*}{ Genus } & \multirow{2}{*}{ Species } & \multicolumn{3}{|c|}{ Nb. Specimens } & \multirow{2}{*}{$\begin{array}{l}\text { Identification } \\
\text { (morph/mol.) }\end{array}$} & \multirow{2}{*}{ GenBank ID (\% Identity) } \\
\hline & & CKGR & OKA & $\mathrm{CHO}$ & & \\
\hline \multirow{2}{*}{ Mansonia } & Ma. africana & 0 & 1290 & 0 & morph/mol. & KU380478 (98.5-99.1) \\
\hline & Ma. uniformis & 0 & 3207 & 0 & morph/mol. & KU187168 (99.8-100) \\
\hline \multirow[t]{2}{*}{ Mimomyia } & Mi. mimomyiaformis & 0 & 1 & 0 & mol. & LC473719 (100) \\
\hline & Mi. splendens & 0 & 2 & 0 & morph/mol. & KU380391 (99.0-99.1) \\
\hline \multirow[t]{2}{*}{ Uranotaenia } & Ur. sp. $1^{1}$ & 0 & 1 & 0 & morph. & - \\
\hline & Ur. sp. $2^{1}$ & 0 & 1 & 0 & morph. & - \\
\hline TOTAL & & 47 & 5266 & 173 & & \\
\hline
\end{tabular}

${ }^{1}$ Specimens unidentified morphologically with no or weak match in GenBank. ${ }^{2}$ Morphologically identified but species absent from GenBank. ${ }^{3}$ Specimens from CKGR and CHO with bad sequences, morphological identification.

The Okavango Delta (OKA) was by far the richest region with 5266 mosquitoes collected ( $96 \%$ of all catches), representing 17 mosquito species and a further 5 unidentified taxa (Table 3, Figure 2b). The area was largely dominated by two Mansonia species ( $M a$. uniformis and Ma. africana), which account for $60.9 \%$ and $24.5 \%$ of the mosquitoes caught in the region, respectively. Other frequent species were $C x$. naevei/simpsoni $(4.35 \%)$ and $C x$. poicilipes $(3.11 \%)$. Seven other species of Culex were caught in the station with lower abundances, ranging from 1 to 111 individuals (Table 3). The proportion of $C x$. pipiens (less than $1 \%$ ) was relatively low compared to their frequency in other regions. Other species were Ae. mcintoshi, seven species of Anopheles (An. gambiae being the most prevalent with $1.41 \%$ of the catches), three species of Coquillettidia (Cq. fuscopennata, Cq. metallica, Cq. microannulata), two species each of Mimomyia (Mi. mimomyiaformis, Mi. splendens) and Uranotaenia (Uranotaenia sp. 1, Uranotaenia sp. 2) (Table 3).

The Central Kalahari Game Reserve (CKGR) reported one species of Aedes (Ae. aegypti, $2.13 \%$ ) and three species of Culex ( $C x$. univittatus, $C x$. perexiguus and $C x$. pipiens) representing $2.13 \%, 6.38 \%$ and $55.32 \%$ of the specimens collected, respectively (Table 3, Figure 2c). It was the least diverse region sampled, and the majority and most abundant species $(C x$. pipiens) was collected at the gate (CKGR_1), where the rangers' camp was located. Other individuals were of three unidentified species of Aedes and one species of Culex, all being relatively rare (three to five specimens).

Okavango reported the highest species richness (22), the Kalahari had the lowest (8) and Chobe was intermediate (12). The species diversity index was highest in the Kalahari (1.491), whereas Chobe had the lowest diversity (0.973) with Okavango being intermediate (1.207). Overall, all the sampled areas had globally important mosquito genera of medical and veterinary importance (Aedes, Anopheles and Culex) with Cx. pipiens species reported in all study sites (Table 4 ). 


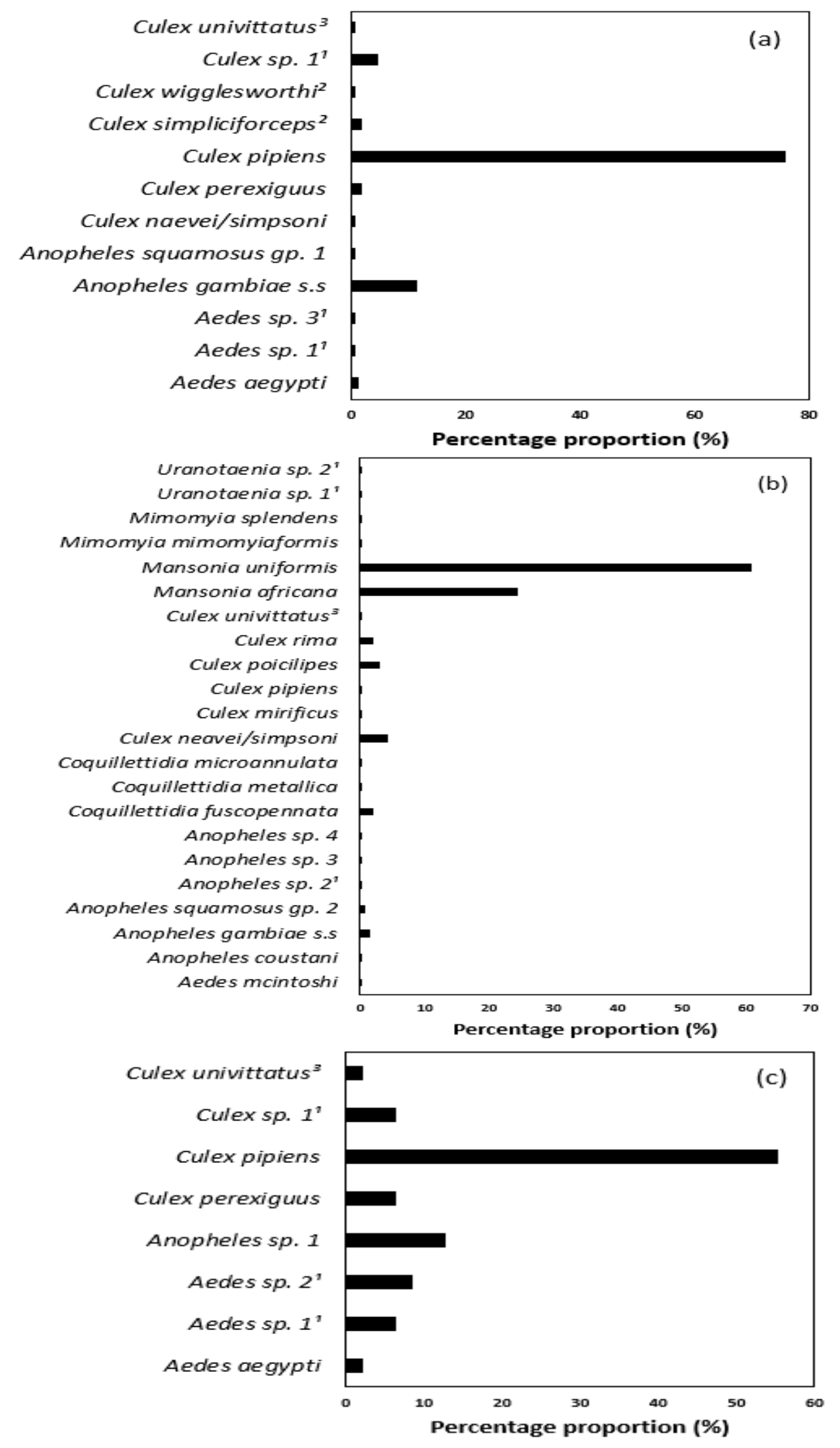

Figure 2. Summary of the diversity proportions (percentage) of mosquito species sampled from the (a) Chobe enclave, (b) Okavango and (c) Central Kalahari Game Reserve (CKGR) between March 2019 and February 2020. 
Table 4. Summary of mosquito species identified from touristic areas (Chobe enclave, Okavango and the Central Kalahari Game Reserve) and their main associated diseases in preferred hosts including humans (H), livestock (L) and wildlife (W).

\begin{tabular}{|c|c|c|c|}
\hline Species & Main Associated Diseases & $\begin{array}{l}\text { Preferred Hosts: Humans (H), } \\
\text { Livestock (L), Wildlife (W) }\end{array}$ & References \\
\hline Aedes aegypti & $\begin{array}{l}\text { Dengue, yellow fever, Zika, } \\
\text { Chikungunya } \\
\text { Lumpy skin disease }\end{array}$ & $\mathrm{H}, \mathrm{L}, \mathrm{W}$ & {$[46,47]$} \\
\hline Aedes mcintoshi & $\begin{array}{l}\text { Rift Valley fever } \\
\text { Human malaria }\end{array}$ & $\mathrm{L}, \mathrm{W}$ & [48] \\
\hline Anopheles coustani & $\begin{array}{l}\text { Rift Valley fever, West Nile fever, } \\
\text { Chikungunya }\end{array}$ & $\mathrm{H}, \mathrm{L}, \mathrm{W}$ & [49] \\
\hline Anopheles gambiae s.s & $\begin{array}{l}\text { Human malaria } \\
\text { Rift Valley fever } \\
\text { Cat-flea typhus } \\
\text { Spotted fever }\end{array}$ & H, L, W & {$[50-52]$} \\
\hline $\begin{array}{l}\text { Anopheles squamosus gp. } 1 \\
\text { Anopheles squamosus gp. } 2\end{array}$ & $\begin{array}{l}\text { Human malaria } \\
\text { Rift Valley fever }\end{array}$ & $\mathrm{H}, \mathrm{W}$ & [53] \\
\hline Coquillettidia fuscopennata & $\begin{array}{l}\text { Avian malaria, Chikungunya, } \\
\text { yellow fever, Sindbis fever }\end{array}$ & $\mathrm{H}, \mathrm{W}$ & [54-56] \\
\hline Coquillettidia metallica & $\begin{array}{c}\text { Avian malaria, West Nile fever, Rift } \\
\text { Valley fever }\end{array}$ & $\mathrm{H}, \mathrm{W}$ & [54-56] \\
\hline Coquillettidia microannulata & Avian malaria & W & {$[55,56]$} \\
\hline Culex naevei & West Nile fever, avian malaria & W & {$[55,57]$} \\
\hline Culex perexiguus & West Nile fever, avian malaria & $\mathrm{H}, \mathrm{W}$ & [58] \\
\hline Culex pipiens & $\begin{array}{c}\text { Rift Valley fever, } \\
\text { West Nile fever, } \\
\text { Filariasis, } \\
\text { Encephalitis, } \\
\text { Avian malaria }\end{array}$ & $\mathrm{H}, \mathrm{L}, \mathrm{W}$ & {$[50,58]$} \\
\hline Culex mirificus & Lumpy skin disease & $\mathrm{L}, \mathrm{W}$ & {$[47,59]$} \\
\hline Culex poicilipes & Rift Valley fever, avian malaria & $\mathrm{L}, \mathrm{W}$ & {$[55,57]$} \\
\hline Culex rima & $\begin{array}{l}\text { West Nile fever, encephalitis, avian } \\
\text { malaria, filariasis }\end{array}$ & $\mathrm{H}, \mathrm{L}, \mathrm{W}$ & {$[60]$} \\
\hline Culex simpliciforceps & & & {$[50,55]$} \\
\hline $\begin{array}{l}\text { Culex sp. } 1 \\
\text { Culex sp. } 2\end{array}$ & Rift Valley fever, avian malaria & $\mathrm{H}, \mathrm{L}, \mathrm{W}$ & \\
\hline Culex univittatus & West Nile fever, Wesselsbron & H, L, W & [54] \\
\hline Mansonia africana & $\begin{array}{c}\text { Rift Valley fever, lymphatic } \\
\text { filariasis, West Nile fever }\end{array}$ & $\mathrm{H}, \mathrm{W}$ & {$[50,54,61,62]$} \\
\hline Mansonia uniformis & $\begin{array}{c}\text { Rift Valley fever, lymphatic } \\
\text { filariasis, } \\
\text { Avian malaria, } \\
\text { West Nile fever, Zika, Chikungunya }\end{array}$ & $\mathrm{H}, \mathrm{W}$ & {$[50,54,55,61,62]$} \\
\hline $\begin{array}{l}\text { Mimomyia mimomyiaformis } \\
\text { Mimomyia splendens }\end{array}$ & West Nile fever & $\mathrm{H}, \mathrm{W}$ & [63] \\
\hline $\begin{array}{l}\text { Uranotaenia sp. } 1 \\
\text { Uranotaenia sp. } 2\end{array}$ & Wesselsbron & $\mathrm{L}$ & [54] \\
\hline
\end{tabular}

\section{Discussions}

The current study documents 32 mosquito taxa (22 identified at the species level and 10 at the genera level) belonging to 7 genera in Botswana's tourism hotspots. To the best of our knowledge, this is the first study to date documenting mosquito species from the Kalahari Desert and one of the few in other major touristic hotspots in Botswana (but see Pachka et al. [30]; Cornel et al. [31]). Congruent to Cornel et al. [31], we found mosquito species of important medical and veterinary concern (see Table 4). In particular, the results showed that $C x$. pipiens dominated other species in the Chobe enclave and CKGR. Most of the $C x$. pipiens in CKGR were collected in a station next to the park entrance (CKGR_1, Figure 1) where people from the park are living, in accordance with its anthropogenic habits 
such as the colonisation of sewage systems. Mansonia uniformis and, to a lesser extent, Ma. africana by far dominated the Okavango area. Mansonia uniformis is known to feed mostly on mammals (e.g., cattle, humans) but readily bites other vertebrate hosts, including avian species $[64,65]$. The alarming high numbers of the duo species should serve as a potential early warning sign of the risk of emerging-re-emerging diseases and pathogen circulation across an interface of humans, livestock and wildlife in the region. This study is also the first to report on the invasive species Ae. aegypti in the Chobe enclave and in the CKGR. It has been observed in Botswana for the first time in the south-east of the country, close to the South African border [36]. Apart from transmitting several pathogens of medical importance (e.g., Zika, dengue, yellow fever and chikungunya viruses), Ae. aegypti has also been reported to transmit lumpy skin virus in cattle [47] and potentially to wildlife. The unidentified species of Aedes (and other unidentified taxa) have implications for the risk of associated diseases in touristic areas; moreover, their pathogenicity status has not yet been assessed. Furthermore, we also report mosquito species belonging to Coquillettidia, Mansonia, Mimomyia and Uranotaenia only in the swampy Okavango, suggesting spatial environmental context effects in determining mosquito species diversity, given the highest richness reported in the area [66].

Differences between the three study sites are likely driven by differences in environmental conditions. The CKGR is more arid, with no permanent water sources supporting mosquito breeding, than to the Chobe enclave and Okavango. Thus, mosquito breeding in the CKGR during dry seasons may be restricted to artificial water holes designed to water wildlife. This may partly account for the fewer mosquito species recorded in the CKGR. Conversely, Okavango consists of semi-permanent basins that are likely to sustain mosquito-breeding success, leading to elevated species richness in the area. For instance, Coquillettidia, Mimomyia and Mansonia species were reported only in the Okavango likely supported by the swampy wetland systems with large clear water bodies, whereby their larvae attach to the submerged aquatic plants for sustained feeding and oxygen intake [67]. The Chobe enclave has permanent water bodies likely to support mosquito species, congruent with Buxton et al. [33]. However, sampling was performed in a relatively arid part of the Chobe enclave, where breeding opportunities are mostly related to the presence of human infrastructure, as indicated by the majority of anthropogenic species found in this region (Ae. aegypti, An. gambiae s.s and Cx. pipiens). Large water bodies, through their semi-permanent swamps, and water that collects in animal hoof prints are a major source of facilitating mosquito-breeding refuge $[33,68]$. Although habitat characterisation was not included in this study, resource portioning and species distribution remains critical for mosquito vector success. This has an implication on the risk of pathogens they may potentially transmit and the distribution of 'previously unidentified' mosquitoes to species level across touristic regions. It is well known that increasing human populations, international travel and globalisation have implications on importing and/or exporting vectors, pathogens and parasites from native ranges or areas of most prevalence [69]. Despite this, however, mosquito diversity from tourism hotspots in Botswana remains relatively unexplored $[30,31,70]$.

The presence of numerous vector species in tourist areas in Botswana, including the invasive Ae. aegypti, a major contributor of dengue infections in the tropics and subtropics globally [71], highlights the need for rigorous mosquito vector surveillance in these areas. Therefore, the use of different trapping techniques in time and space may be essential in exploring a full spectrum of mosquito species diversity across varying seasonal and environmental niches [72]. More robust and spatially even sampling protocols with standardised effort may also be needed to get more accurate diversity indices across the studied sites. Furthermore, pathogen screening in vectors and prevailing vertebrate hosts (humans, livestock and wildlife) is pivotal in assessing transmission dynamics and the potential risk of emerging and re-emerging diseases in the country. This study also reported $C x$. pipiens mosquitoes, which exist as a species complex. Thus, future studies may explore genetic variation among sibling species and consider surveillance of the diversity 
of other arthropod vectors capable of incriminating humans, livestock and wildlife with their associated pathogens. This study nevertheless provides significant baseline vector diversity data that may play a significant role in identifying infection risk pathways in pest and disease risk analysis and under emerging and re-emerging vector-borne infections.

Author Contributions: Project conceptualisation and management: C.N., P.C., O.G. Funding: M.B., C.N., R.J.W., R.P., O.G., P.C. Data curation: O.G., P.C., R.P., V.O.-G. Formal analysis: M.B., C.N., R.J.W., O.G., P.C. Investigation: M.B., C.N., O.G., R.P., P.C. Visualisation and validation: M.B., C.N., R.J.W., O.G., R.P., P.C. Writing - original draft: M.B., C.N., R.J.W. Writing, review and editing: M.B., C.N., R.J.W., O.G., R.P., P.C. All authors have read and agreed to the published version of the manuscript.

Funding: The research was funded by the University of Lausanne and the Swiss National Science Foundation, grant number 31003A_179378. Also, funding was secured from the Botswana International University of Science and Technology, grant numbers DVC/2/1/13 XI and DVC/RDI/2/1/7 V (18). The APC was funded by the University of Lausanne.

Institutional Review Board Statement: The study was conducted under the approval of the Ministry of Environment, Natural Resources Conservation and Tourism, Botswana (research permit: ENT 8/36/4 XXX II [10]).

Informed Consent Statement: Not applicable.

Data Availability Statement: The datasets during and/or analysed during the current study are available from the corresponding author on reasonable request.

Acknowledgments: We thank the Botswana International University of Science and Technology (BIUST) for providing funding and infrastructure support to M.B., C.N. and R.J.W., the University of Lausanne and the Swiss National Science Foundation, grant number 31003A_179378, for funding R.P. and P.C. and the Museum of Zoology in Lausanne for funding O.G. The VanThuyne-Ridge (VTR) Research Centre is acknowledged for providing research facilities and infrastructure. In addition, we thank the Ministry of Environment, Natural Resources Conservation and Tourism (Botswana) for the issuing of a research permit (ENT 8/36/4 XXX II [10]). Further, we sincerely acknowledge the contributions made by Chiswaniso Picture Kakambi, Ali Muchuka Mainga, Julie Glaizot, Kealeboga Matshameko and Mogomotsi Mokgadi in data collection and field work proceedings. We also thank Molly Baur and Jérôme Wassef for the molecular identification of mosquito species.

Conflicts of Interest: All authors declare no conflict of interests.

\section{References}

1. Portillo, A.; Ruiz-Arrondo, I.; Oteo, J.A. Arthropods as vectors of transmissible diseases in Spain. Med. Clin. 2018, 151, 450-459. [CrossRef]

2. Santos, J.C.; de Almeida, W.R.; Fernandes, G.W. Arthropods: Why It Is So Crucial to Know Their Biodiversity? In Measuring Arthropod Biodiversity; Springer International Publishing: Cham, Switzerland, 2021; pp. 3-11.

3. Lebl, K.; Zittra, C.; Silbermayr, K.; Obwaller, A.; Berer, D.; Brugger, K.; Rubel, F. Mosquitoes (Diptera: Culicidae) and their relevance as disease vectors in the city of Vienna, Austria. Parasitol. Res. 2015, 114, 707-713. [CrossRef]

4. Rizzoli, A.; Tagliapietra, V.; Cagnacci, F.; Marini, G.; Arnoldi, D.; Rosso, F.; Rosà, R. Parasites and wildlife in a changing world: The vector-host-pathogen interaction as a learning case. Int. J. Parasitol. Parasites Wildl. 2019, 9, 394-401. [CrossRef]

5. Azari-Hamidian, S.; Norouzi, B.; Harbach, R.E. A detailed review of the mosquitoes (Diptera: Culicidae) of Iran and their medical and veterinary importance. Acta Trop. 2019, 194, 106-122. [CrossRef] [PubMed]

6. Sinka, M.E.; Bangs, M.J.; Manguin, S.; Rubio-Palis, Y.; Chareonviriyaphap, T.; Coetzee, M.; Hay, S.I. A global map of dominant malaria vectors. Parasites Vectors 2012, 5, 1-11. [CrossRef]

7. Carlson, J.S.; Walther, E.; TroutFryxell, R.; Staley, S.; Tell, L.A.; Sehgal, R.N.; Cornel, A.J. Identifying avian malaria vectors: Sampling methods influence outcomes. Parasites Vectors 2015, 8, 1-16. [CrossRef] [PubMed]

8. Sang, R.; Arum, S.; Chepkorir, E.; Mosomtai, G.; Tigoi, C.; Sigei, F.; Evander, M. Distribution and abundance of key vectors of Rift Valley fever and other arboviruses in two ecologically distinct counties in Kenya. PLoS Negl. Trop. Dis. 2017, 11, e0005341. [CrossRef] [PubMed]

9. Braack, L.; De Almeida, A.P.G.; Cornel, A.J.; Swanepoel, R.; De Jager, C. Mosquito-borne arboviruses of African origin: Review of key viruses and vectors. Parasites Vectors. 2018, 11, 1-26. [CrossRef]

10. Nkumama, I.N.; O'Meara, W.P.; Osier, F.H. Changes in malaria epidemiology in Africa and new challenges for elimination. Trends Parasitol. 2017, 33, 128-140. [CrossRef] [PubMed] 
11. Seebens, H.; Blackburn, T.M.; Dyer, E.E.; Genovesi, P.; Hulme, P.E.; Jeschke, J.M.; Essl, F. No saturation in the accumulation of alien species worldwide. Nat. Commun. 2017, 8, 1-9. [CrossRef]

12. Chaves, L.S.M.; Fry, J.; Malik, A.; Geschke, A.; Sallum, M.A.M.; Lenzen, M. Global consumption and international trade in deforestation-associated commodities could influence malaria risk. Nat. Commun. 2020, 11, 1-10. [CrossRef]

13. Schrama, M.; Hunting, E.R.; Beechler, B.R.; Guarido, M.M.; Govender, D.; Nijland, W.; Gorsich, E.E. Human practices promote presence and abundance of disease-transmitting mosquito species. Sci. Rep. 2020, 10, 1-6. [CrossRef]

14. Diagne, C.; Leroy, B.; Vaissière, A.C.; Gozlan, R.E.; Roiz, D.; Jarić, I.; Courchamp, F. High and rising economic costs of biological invasions worldwide. Nature 2021, 592, 571-576. [CrossRef] [PubMed]

15. Renault, D.; Angulo, E.; Cuthbert, R.; Haubrock, P.J.; Capinha, C.; Kramer, A.M.; Courchamp, F. The magnitude, diversity, and distribution of the economic costs of invasive terrestrial invertebrates worldwide. Biol. Invasions 2021, 23. [CrossRef]

16. Carvajal-Lago, L.; Ruiz-López, M.J.; Figuerola, J.; Martínez-de la Puente, J. Implications of diet on mosquito life history traits and pathogen transmission. Environ. Res. 2021, 195, 110893. [CrossRef] [PubMed]

17. Cunze, S.; Kochmann, J.; Koch, L.K.; Klimpel, S. Niche conservatism of Aedes albopictus and Aedes aegypti-two mosquito species with different invasion histories. Sci. Rep. 2018, 8, 1-10. [CrossRef] [PubMed]

18. Munyao, V.; Karisa, J.; Munyao, C.M.; Ngari, M.; Menza, N.; Peshu, N.; Mwangangi, J. Surveillance of Culicine Mosquitoes in Six Villages of Taita-Taveta County, Kenya, With Host Determinations From Blood-Fed Females. J. Med. Entomol. 2020, 57, 1972-1982. [CrossRef] [PubMed]

19. Joannides, J. Species Composition and Risk of Transmission of Aedes-Borne Arboviruses around the Mole Game Reserve in Northern Ghana. Ph.D. Thesis, University of Ghana, Accra, Ghana, 2019.

20. Mbacham, W.F.; Ayong, L.; Guewo-Fokeng, M.; Makoge, V. Current Situation of Malaria in Africa. In Malaria Control and Elimination; Humana Press: New York, NY, USA, 2019; pp. 29-44.

21. Willcox, A.C.; Collins, M.H.; Jadi, R.; Keeler, C.; Parr, J.B.; Mumba, D.; Meshnick, S.R. Seroepidemiology of dengue, Zika, and yellow fever viruses among children in the Democratic Republic of the Congo. Am. J. Trop. Med. Hyg. 2018, 99, 756-763. [CrossRef] [PubMed]

22. Mwanyika, G.O.; Mboera, L.E.; Rugarabamu, S.; Ngingo, B.; Sindato, C.; Lutwama, J.J.; Misinzo, G. Dengue Virus Infection and Associated Risk Factors in Africa: A Systematic Review and Meta-Analysis. Viruses 2021, 13, 536. [CrossRef]

23. Dyer, O. African malaria deaths set to dwarf covid-19 fatalities as pandemic hits control efforts, WHO warns. BMJ 2020, 371, $\mathrm{m} 4711$. [CrossRef]

24. Stevenson, J.C.; Norris, D.E. Implicating cryptic and novel anophelines as malaria vectors in Africa. Insects 2017, 8, 1. [CrossRef]

25. Kgoroebutswe, T.K.; Ramatlho, P.; Reeder, S.; Makate, N.; Paganotti, G.M. Distribution of Anopheles mosquito species, their vectorial role and profiling of knock-down resistance mutations in Botswana. Parasitol. Res. 2020, 119, 1201-1208. [CrossRef]

26. Tawe, L.; Ramatlho, P.; Waniwa, K.; Muthoga, C.W.; Makate, N.; Ntebela, D.S.; Paganotti, G.M. Preliminary survey on Anopheles species distribution in Botswana shows the presence of Anopheles gambiae and Anopheles funestus complexes. Malar. J. 2017, 16, 1-7. [CrossRef] [PubMed]

27. Leechor, C. Developing Tourism in Botswana: Progress and Challenges; Botswana Documents; Botswana institute for Development Policy Analysis: Gaborone, Botswana, 2017.

28. Stone, T.M.; Mbaiwa, J.E.; Stone, L.S. Tourism in Botswana in the last 50 years: A review. Botsw. Notes Rec. $2017,49,57-72$.

29. Magole, L.I.; Gojamang, O. The dynamics of tourist visitation to national parks and game reserves in Botswana. Botsw. Notes Rec. 2005, 37, 80-96.

30. Pachka, H.; Annelise, T.; Alan, K.; Power, T.; Patrick, K.; Véronique, C.; Ferran, J. Rift Valley fever vector diversity and impact of meteorological and environmental factors on Culex pipiens dynamics in the Okavango Delta, Botswana. Parasites Vectors 2016, 9 , 1-17. [CrossRef]

31. Cornel, A.J.; Lee, Y.; Almeida, A.P.G.; Johnson, T.; Mouatcho, J.; Venter, M.; Braack, L. Mosquito community composition in South Africa and some neighboring countries. Parasites Vectors 2018, 11, 1-12. [CrossRef] [PubMed]

32. Karypidou, M.C.; Almpanidou, V.; Tompkins, A.M.; Mazaris, A.D.; Gewehr, S.; Mourelatos, S.; Katragkou, E. Projected shifts in the distribution of malaria vectors due to climate change. Clim. Chang. 2020, 163, 2117-2133. [CrossRef]

33. Buxton, M.; Wasserman, R.J.; Nyamukondiwa, C. Disease Vector Relative Spatio-Temporal Abundances to Water Bodies and Thermal Fitness Across Malaria Endemic Semi-Arid Areas. J. Med. Entomol. 2021, 58, 682-691. [CrossRef]

34. Bango, Z.A.; Tawe, L.; Muthoga, C.W.; Paganotti, G.M. Past and current biological factors affecting malaria in the low transmission setting of Botswana: A review. Infect. Genet. Evol. 2020, 85, 104458. [CrossRef]

35. Abdulla-Khan, R. Bionomics and cytogenetics of Anopheles seretsei Abdulla-Khan, Coetzee, and Hunt, a new species from northern Botswana. J. Am. Mosq. Control. Assoc. 1998, 14, 253-255.

36. Buxton, M.; Lebani, K.; Nyamukondiwa, C.; Wasserman, R.J. First record of Aedes (Stegomyia) aegypti (Linnaeus, 1762) (Diptera: Culicidae) in Botswana. Bioinvasions Rec. 2019, 8, 551-557. [CrossRef]

37. Buxton, M.; Cuthbert, R.N.; Dalu, T.; Nyamukondiwa, C.; Wasserman, R.J. Cattle-induced eutrophication favours disease-vector mosquitoes. Sci. Total Environ. 2020, 715, 136952. [CrossRef]

38. Johnson, T.; Braack, L.; Guarido, M.; Venter, M.; Gouveia Almeida, A.P. Mosquito community composition and abundance at contrasting sites in northern South Africa, 2014-2017. J. Vector Ecol. 2020, 45, 104-117. [CrossRef] 
39. Mishra, N.B.; Crews, K.A.; Miller, J.A.; Meyer, T. Mapping vegetation morphology types in southern Africa savanna using MODIS time-series metrics: A case study of central Kalahari, Botswana. Land 2015, 4, 197-215. [CrossRef]

40. Ramberg, L.; Hancock, P.; Lindholm, M.; Meyer, T.; Ringrose, S.; Sliva, J.; Vander Post, C. Species diversity of the Okavango delta, Botswana. Aquat. Sci. 2006, 68, 310-337. [CrossRef]

41. Makhabu, S.W. Resource partitioning within a browsing guild in a key habitat, the Chobe Riverfront, Botswana. J. Trop. Ecol. 2005, 21, 641-649. [CrossRef]

42. Jori, F.; Mokospasetso, M.; Etter, E.; Munstermann, S.; Newman, S.H.; Michel, A. Preliminary Assessment of Bovine Tuberculosis at the Livestock/Wildlife Interface in two Protected Areas of Northern Botswana. Transbound. Emerg. Dis. 2013, 60, 28-36. [CrossRef] [PubMed]

43. Jupp, P.G. Mosquitoes of Southern Africa: Culicinae and toxorhynchitinae; Ekogilde Publishers: Hartebeespoort, South Africa, 1996.

44. Folmer, O.; Black, M.; Hoeh, W.; Lutz, R.; Vrijenhoek, R. DNA primers for amplification of mitochondrial cytochrome c oxidase subunit I from diverse metazoan invertebrates. Mol. Mar. Biol. Biotechnol. 1994, 3, 294-299. [PubMed]

45. Khoobdel, M.; Keshavarzi, D.; Mossa-Kazemi, S.H.; Sobati, H. Species diversity of mosquitoes of the Genus Culex (Diptera, Culicidae) in the coastal areas of the Persian Gulf. AIMS Public Health 2019, 6, 99. [CrossRef] [PubMed]

46. Weetman, D.; Kamgang, B.; Badolo, A.; Moyes, C.L.; Shearer, F.M.; Coulibaly, M.; McCall, P.J. Aedes mosquitoes and Aedes-borne arboviruses in Africa: Current and future threats. Int. J. Environ. Res. Public Health 2018, 15, 220. [CrossRef] [PubMed]

47. Sprygin, A.; Pestova, Y.; Wallace, D.B.; Tuppurainen, E.; Kononov, A.V. Transmission of lumpy skin disease virus: A short review. Virus Res. 2019, 269, 197637. [CrossRef] [PubMed]

48. Campbell, L.P.; Reuman, D.C.; Lutomiah, J.; Peterson, A.T.; Linthicum, K.J.; Britch, S.C.; Sang, R. Predicting Abundances of Aedes mcintoshi, a primary Rift Valley fever virus mosquito vector. PLoS ONE 2019, 14, e0226617. [CrossRef] [PubMed]

49. Goupeyou-Youmsi, J.; Rakotondranaivo, T.; Puchot, N.; Peterson, I.; Girod, R.; Vigan-Womas, I.; Bourgouin, C. Differential contribution of Anopheles coustani and Anopheles arabiensis to the transmission of Plasmodium falciparum and Plasmodium vivax in two neighbouring villages of Madagascar. Parasites Vectors 2020, 13, 1-16. [CrossRef]

50. Tantely, L.M.; Boyer, S.; Fontenille, D. A review of mosquitoes associated with Rift Valley fever virus in Madagascar. Am. J. Trop. Med. Hyg. 2015, 92, 722-729. [CrossRef] [PubMed]

51. Barreaux, A.M.; Stone, C.M.; Barreaux, P.; Koella, J.C. The relationship between size and longevity of the malaria vector Anopheles gambiae (ss) depends on the larval environment. Parasites Vectors 2018, 11, 1-9. [CrossRef]

52. Socolovschi, C.; Pages, F.; Ndiath, M.O.; Ratmanov, P.; Raoult, D. Rickettsia species in African Anopheles mosquitoes. PLoS ONE 2012, 7, e48254. [CrossRef]

53. Fornadel, C.M.; Norris, L.C.; Franco, V.; Norris, D.E. Unexpected anthropophily in the potential secondary malaria vectors Anopheles coustani sl and Anopheles squamosus in Macha, Zambia. Vector Borne Zoonotic Dis. 2011, 11, 1173-1179. [CrossRef]

54. Mutebi, J.P.; Crabtree, M.B.; Kading, R.C.; Powers, A.M.; Lutwama, J.J.; Miller, B.R. Mosquitoes of western Uganda. J. Med. Entomol. 2014, 49, 1289-1306. [CrossRef]

55. Njabo, K.Y.; Cornel, A.J.; Bonneaud, C.; Toffelmier, E.; Sehgal, R.N.M.; Valkiūnas, G.; Smith, T.B. Nonspecific patterns of vector, host and avian malaria parasite associations in a central African rainforest. Mol. Ecol. 2011, 20, 1049-1061. [CrossRef] [PubMed]

56. Njabo, K.Y.; Cornel, A.J.; Sehgal, R.N.; Loiseau, C.; Buermann, W.; Harrigan, R.J.; Smith, T.B. Coquillettidia (Culicidae, Diptera) mosquitoes are natural vectors of avian malaria in Africa. Malar. J. 2009, 8, 1-12. [CrossRef] [PubMed]

57. Fall, A.G.; Diaïté, A.; Lancelot, R.; Tran, A.; Soti, V.; Etter, E.; Bouyer, J. Feeding behaviour of potential vectors of West Nile virus in Senegal. Parasites Vectors 2011, 4, 1-7. [CrossRef]

58. Ferraguti, M.; Heesterbeek, H.; Martínez-de la Puente, J.; Jiménez-Clavero, M.Á.; Vázquez, A.; Ruiz, S.; Figuerola, J. The role of different Culex mosquito species in the transmission of West Nile virus and avian malaria parasites in Mediterranean areas. Transbound. Emerg. Dis. 2020, 68, 920-930. [CrossRef]

59. Woods, J.A. Lumpy Skin Disease Virus. In Virus Infections of Ruminants; Elsevier Science publishers: Amsterdam, The Netherlands, 1990; pp. 53-67.

60. Traoré, M.; Ouattara, A.F.; Coulibaly, D.; GN, C.; Gbalégba, D.S.T.; Kwadjo, K.E.; Doumbia, M. Assessment of the risk of mosquitoes nuisance and appearance of vector-borne diseases in rubber production areas in Southern Côte d'Ivoire. J. Entomol. Zool. Stud. 2019, 7, 322-329.

61. Ughasi, J.; Bekard, H.E.; Coulibaly, M.; Adabie-Gomez, D.; Gyapong, J.; Appawu, M.; Boakye, D.A. Mansonia africana and Mansonia uniformis are vectors in the transmission of Wuchereria bancrofti lymphatic filariasis in Ghana. Parasites Vectors 2012, 5 , 1-5. [CrossRef]

62. Osei-Poku, J.; Han, C.; Mbogo, C.M.; Jiggins, F.M. Identification of Wolbachia strains in mosquito disease vectors. PLoS ONE 2012, 7, e49922. [CrossRef] [PubMed]

63. Traore-Lamizana, M.; Zeller, H.G.; Mondo, M.; Hervy, J.P.; Adam, F.; Digoutte, J.P. Isolations of West Nile and Bagaza viruses from mosquitoes (Diptera: Culicidae) in central Senegal (Ferlo). J. Med. Entomol. 1994, 31, 934-938. [CrossRef]

64. Sabesan, S.; Kumar, N.P.; Krishnamoorthy, K.; Panicker, K.N. Seasonal abundance and biting behaviour of Mansonia annulifera. M. uniformis and M. indiana and their relative role in the transmission of malayan filariasis in shertallai (Kerala state). Indian J. Med. Res. 1991, 93, 253-258. 
65. Ridha, M.R.; Rahayu, N.; Hairani, B.; Perwitasari, D.; Kusumaningtyas, H. Biodiversity of mosquitoes and Mansonia uniformis as a potential vector of Wuchereria bancrofti in Hulu Sungai Utara District, South Kalimantan, Indonesia. Vet. World 2020, $13,2815$. [CrossRef]

66. Zittra, C.; Vitecek, S.; Obwaller, A.G.; Rossiter, H.; Eigner, B.; Zechmeister, T.; Waringer, J.; Fuehrer, H.P. Landscape structure affects distribution of potential disease vectors (Diptera: Culicidae). Parasites Vectors 2017, 10, 205. [CrossRef]

67. Johnson, P.H.; Russell, R.C. Colonization of Coquillettidia linealis (Skuse) with reference to other Coquillettidia and Mansonia species. J. Vector Ecol. 2019, 44, 130-137. [CrossRef]

68. Dida, G.O.; Anyona, D.N.; Abuom, P.O.; Akoko, D.; Adoka, S.O.; Matano, A.S.; Ouma, C. Spatial distribution and habitat characterization of mosquito species during the dry season along the Mara River and its tributaries, in Kenya and Tanzania. Infect. Dis. Poverty 2018, 7, 1-16. [CrossRef] [PubMed]

69. Tatem, A.J. Mapping population and pathogen movements. Int. Health 2014, 6, 5-11. [CrossRef]

70. Chirebvu, E.; Chimbari, M.J. Characteristics of Anopheles arabiensis larval habitats in Tubu village, Botswana. J. Vector Ecol. 2015, 40, 129-138. [CrossRef] [PubMed]

71. Ong, J.; Aik, J.; Ng, L.C. Adult Aedes abundance and risk of dengue transmission. PLoS Negl. Trop. Dis. 2021, 15, e0009475. [CrossRef] [PubMed]

72. Kline, D.L. Traps and trapping techniques for adult mosquito control. J. Am. Mosq. Control. Assoc. 2006, 22, 490-496. [CrossRef] 